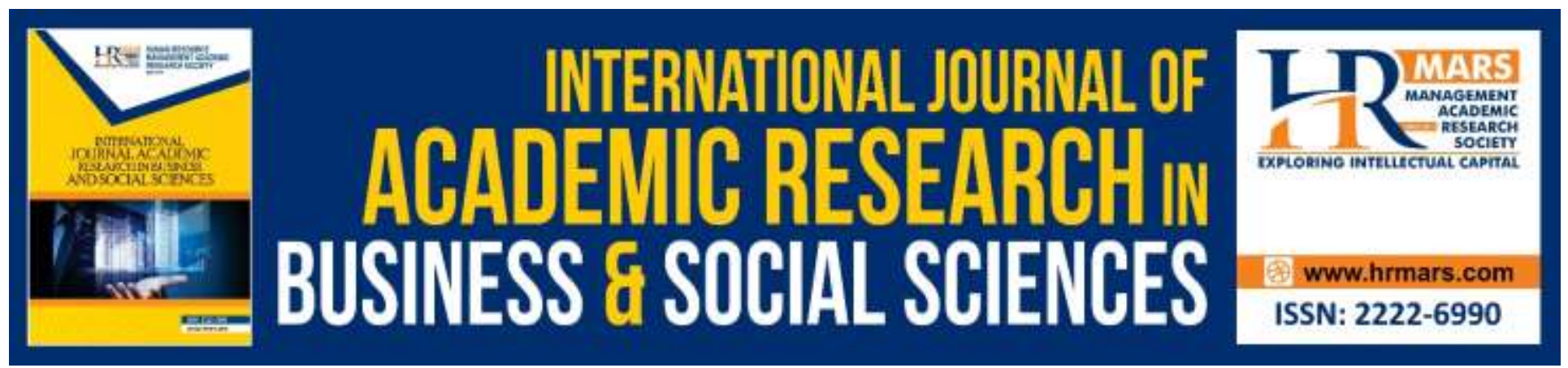

\title{
Correlation Between Teachers' Teaching Styles and Pupils' Ujian Pencapaian Sekolah Rendah (UPSR) Results
}

\section{Estee-Laura Anak Anthony \& Hamidah Yamat}

To Link this Article: http://dx.doi.org/10.6007/IJARBSS/v10-i3/7018
DOI:10.6007/IJARBSS/v10-i3/7018

Received: 22 January 2020, Revised: 06 February 2020, Accepted: 29 February 2020

Published Online: 22 March 2020

In-Text Citation: (Anthony \& Yamat, 2020)

To Cite this Article: Anthony, E.-L. A., Yamat, H. (2020). Correlation Between Teachers' Teaching Styles and Pupils' Ujian Pencapaian Sekolah Rendah (UPSR) Results. International Journal of Academic Research in Business and Social Sciences, 10(3), 17-28.

Copyright: (c) 2020 The Author(s)

Published by Human Resource Management Academic Research Society (www.hrmars.com) This article is published under the Creative Commons Attribution (CC BY 4.0) license. Anyone may reproduce, distribute, translate and create derivative works of this article (for both commercial and non-commercial purposes), subject to full attribution to the original publication and authors. The full terms of this license may be seen at: http://creativecommons.org/licences/by/4.0/legalcode

Vol. 10, No. 3, 2020, Pg. $17-28$

Full Terms \& Conditions of access and use can be found at http://hrmars.com/index.php/pages/detail/publication-ethics 


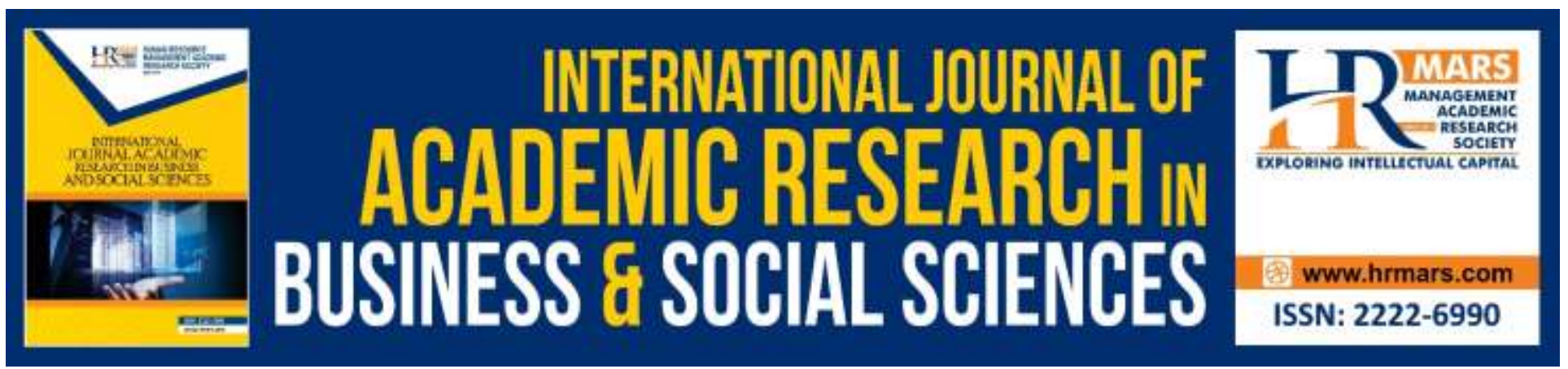

\title{
Correlation Between Teachers' Teaching Styles and Pupils' Ujian Pencapaian Sekolah Rendah (UPSR) Results
}

\author{
Estee-Laura Anak Anthony ${ }^{1} \&$ Hamidah Yamat ${ }^{2}$ \\ Sekolah Kebangsaan Sungai Genaan, Sebauh ${ }^{1}$, Fakulti Pendidikan, Universiti Kebangsaan Malaysia ${ }^{2}$ \\ Email: nizela.el@gmail.com ${ }^{1}$, hamidah_yamat@ukm.edu.my ${ }^{2}$
}

\begin{abstract}
English Language is one of the important subjects being taught in schools. It is also included as a compulsory subject in national level examinations in Malaysia. Despite its significance in education, English Language is considered as a killer subject among pupils and the teachers themselves especially in rural areas. This could be seen from the unsatisfying results every year. Thus, this study was aimed at determining the correlation between teachers' teaching styles and pupils' achievements in UPSR particularly in English Language Subject. The respondents of this study were of 10 teachers from 5 respective rural schools in Tatau District. These respondents were purposely chosen based on their schools' UPSR results for 3 consecutive years. The data on teachers' profile such as gender, teaching experience and option are also collected through survey. Based on the findings, all 5 teaching styles were employed. The findings also demonstrated that Delegator style was the dominant teaching style used by the teachers. Through this study, it is hoped that more teachers are willing to diversify their teaching styles to help pupils achieve greater results in examination.
\end{abstract}

Keywords: Correlation, Teachers, Teaching Styles, Pupils, Results

\section{Introduction}

Teachers are the role models and exemplars in the society. It is also true that teacher is the light in the classroom (Barberos, Gozalo \& Padayogdog, 2019). As teachers, we play important roles in our pupils' learning. It is also a teacher's accountability to be able to maintain pupils' interest in learning by adapting various teaching styles in classroom (Erikson, 1978). In Malaysia, one of the agendas outlined by the MOE is to ensure a good quality of education for all pupils. To produce equally competent and educated Malaysian students, national level examinations are introduced in primary school and secondary school level. In primary school, by the end of 6-year schooling, pupils all over Malaysia will have to sit for UPSR examination which is usually done in September every year. 
This clearly means that pupils have roughly 6 years to prepare themselves before taking this examination. Similarly, Year 6 teachers have major responsibility to equip the pupils so that they can pass the examination with flying colours. One of the ways to equip the pupils with enough and longlasting knowledge is to employ effective teaching styles.

Every year, UPSR results will come out by November, which is highly anticipated by parents, teachers and pupils. Pupils who achieved good grades in UPSR are perceived as being successfully educated by their teachers. In other words, the teachers' teaching goals are already achieved. However, there are still pupils who could not pass with good grades in UPSR, particularly in English Language. Does this mean the teachers did not successfully teach their pupils? Were their teaching goals not achieved? Or does this imply that failed pupils are driven by the ineffective teaching styles used by the teachers? These questions are the driving forces to the implementation of this study, which is to determine the correlation between teachers' teaching styles and pupils' achievement in UPSR.

This study aims to answer the following question:

1. Is there any correlation between teachers' teaching style and pupils' UPSR achievements?

\section{Literature Review}

Pupils' achievement in English Language is vastly determined by teachers' teaching styles (Muena, Mulwa \& Mailu, 2018). Since Malaysia is a country practising English as Second Language, this does not indicate that English Language is less important than the first language. In fact, English Language is perceived as the language of business and communication and job opportunities by many individuals. Therefore, it is understandable that English Language is given the same priority as compulsory subject in all levels of education, from pre-schools to higher learning institutions.

According to Akinbute (2007), primary school years are the most vital years for pupils. This is because pupils learn a lot of basic knowledge at primary school level for the sake of their future education. This is supported by Ebrahimi (2016), who stated that the knowledge and insight from primary school education lays strong foundation for higher learning. This clearly shows the significance of using effective teaching styles among teachers.

This study is closely related to the previous studies on the effect of teaching styles on pupils' achievement. Over the past few years, a several amounts of research have affirmed the strong relationship between teachers' teaching styles and the academic achievement of pupils. Nayan (2011) conducted a survey to compare the teaching styles between Level 1 and Level 2 primary school teachers. The survey was adapted from Grasha's teaching styles which involved 30 teachers in SK Seri Ampang Muda, Kedah. The results from this study demonstrated the application of three main teaching styles namely Formal Authority Style, Expert Style and Delegator Style.

A study in 2014 conducted by Shaari et al. had touched on the relationship between lecturer's teaching style and students' academic engagement in Universiti Utara Malaysia. It is found out that personal model style is the most popular teaching style among the lecturers whereas delegator style is the least popular. The study also showed a moderately significant relationship between lecturers' teaching style with the students' academic engagement.

In addition, a study on comparison of teaching styles between teachers teaching Malay Language and English Language was conducted by Zamri, Nik \& Juliawati (2009) in Hulu Langat district, Selangor. Using survey method, 300 teachers were selected as respondents in order to 
INTERNATIONAL JOURNAL OF ACADEMIC RESEARCH IN BUSINESS AND SOCIAL SCIENCES

Vol. 10, No. 3, March, 2020, E-ISSN: 2222-6990 C 2020 HRMARS

identify their teaching styles based on their teaching subjects. The results showed the use of all five teaching styles.

\section{Teaching Styles by Grasha}

According to Grasha (1994), there are 5 categories of teaching styles employed by teachers. The categories are namely Expert style, Formal Authority style, Personal Modal style, Facilitator style and Delegator Style. These teaching styles are developed by him with the purposes to describe the qualities owned by teachers and to provide suggestions on when and how to use them (Grasha, 1994).

\section{Expert Style}

Teachers who employs Expert style has knowledge and expertise that pupils need. They also attempt to maintain status as an expert among pupils by exhibiting detailed knowledge. Teachers who possess this quality strives to challenge pupils to improve their performance in learning. Finally, they focus on conveying information, and demands pupils to be equipped to learn and use the information.

\section{Formal Authority Style}

Teachers who possess Formal Authority style owns status among pupils because of their knowledge and roles. They also tend to deliver positive and negative feedback to pupils. Besides that, the teachers create learning expectations and rules which provides pupils an insight of the learning structure. Lastly, teachers who have this quality also require pupils to focus on correct, acceptable and standard techniques.

\section{Personal Model Style}

Teachers who employs Personal Model style stands on belief that teaching is a process of portraying personal example. They also create a model for thinking and behaviour, then guides pupils by modelling how to do things. Finally, a Personal Model teacher motivates pupils to observe and imitate the teacher's method.

\section{Facilitator Style}

Teachers who have the quality of Facilitator style highlights the teacher-pupil communications. They also guide and direct their pupils by asking questions, exploring choices and suggesting other opportunities. Furthermore, this type of teachers stresses on the independent choice, action and responsibility. At last, teachers who possess facilitator style accommodate pupils with as much support and encouragement of possible.

\section{Delegator Style}

Teachers who possess the characteristics of Delegator style have tendency to help pupils see themselves as independent learners. They also perceive themselves as resource person in classroom. In other words, teachers who employ this style in classroom encourage pupils to complete their tasks independently or as part of self-directed teams. 
INTERNATIONAL JOURNAL OF ACADEMIC RESEARCH IN BUSINESS AND SOCIAL SCIENCES

Vol. 10, No. 3, March, 2020, E-ISSN: 2222-6990 C 2020 HRMARS

\section{Pupils' Achievement}

Pupils can be described as children who are being taught by teachers at school (Cambridge Dictionary, 2019). Pupils mentioned in this study are particularly Year 6 pupils. During their sixth year in primary school, they will have to sit for Ujian Penilaian Sekolah Rendah (UPSR). Simpson \& Weiner (1989) defined achievement as "measurable behaviour in a standardised series of tests. In this study, UPSR is a standardised test developed for national primary school pupils in Malaysia which is usually held in September every year.

Table 1: UPSR Results for English Language Paper 1 \& 2

\begin{tabular}{|c|c|c|c|c|c|c|}
\hline School & \multicolumn{2}{|c|}{$\begin{array}{c}\text { UPSR 2016 } \\
\text { (\%passed) }\end{array}$} & \multicolumn{2}{c|}{$\begin{array}{c}\text { UPSR 2017 } \\
\text { (\%passed) }\end{array}$} & \multicolumn{2}{c|}{ UPSR 2018 (\%passed) } \\
\hline English Paper & 1 & 2 & 1 & 2 & 1 & 2 \\
\hline SK A & 57.89 & 68.42 & 66.67 & 50.00 & 95.83 & 66.67 \\
\hline SK B & 47.06 & 52.94 & 100.00 & 62.50 & 100.00 & 40.00 \\
\hline SK C & 100.00 & 100.00 & 100.00 & 66.67 & 100.00 & 60.00 \\
\hline SK D & 91.67 & 83.88 & 68.75 & 50.00 & 92.86 & 85.71 \\
\hline SK E & 85.71 & 85.71 & 93.75 & 87.50 & 100.00 & 100.00 \\
\hline
\end{tabular}

\section{Conceptual Framework}

The conceptual framework of this study is based on the Teachers' Teaching Style Model introduced by Grasha (1994). There are 5 types of teaching styles according to Grasha (1994), namely Expert Style, Authority Formal Style, Personal Model Style, Facilitator Style and Delegator Style. As can be seen in Figure 1, the conceptual framework of this study includes 5 teaching styles proposed by Grasha. The independent variable of this study is Year 6 English Language teachers' teaching style. Meanwhile, pupils' UPSR achievement is the dependent variable. Teachers' teaching style are also determined according to their gender, option and teaching experience. In other words, pupils' achievement in UPSR are influenced by their teachers' teaching style.

Figure 1: Conceptual Framework adapted from Grasha's Teaching Styles

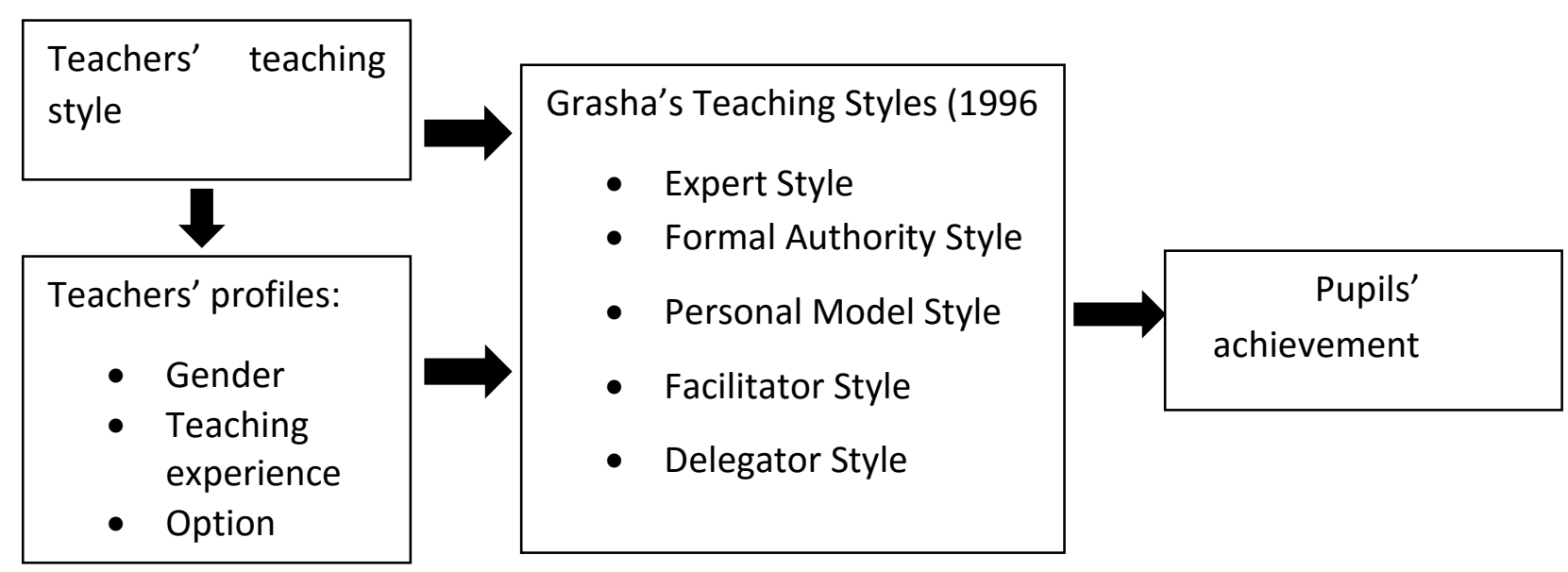


INTERNATIONAL JOURNAL OF ACADEMIC RESEARCH IN BUSINESS AND SOCIAL SCIENCES

Vol. 10, No. 3, March, 2020, E-ISSN: 2222-6990 C 2020 HRMARS

\section{Methodology}

Tatau is a small sub-district located near Bintulu, Sarawak. The mean of transportation to most of the rural primary schools is by road. 10 English teachers from 5 rural schools in Tatau are purposely selected as respondents. The table below shows the number of respondents for this study:

Table 2: Number of Year 6 English Language Teachers in Tatau

\begin{tabular}{cc}
\hline School Name & Number of Year $\mathbf{6}$ teachers \\
\hline Sekolah Kebangsaan A & 2 \\
\hline Sekolah Kebangsaan B & 2 \\
\hline Sekolah Kebangsaan C & 2 \\
\hline Sekolah Kebangsaan D & 2 \\
\hline Sekolah Kebangsaan E & 2 \\
\hline Total & 10 \\
\hline
\end{tabular}

Source: Data from PPD Tatau, 2019

\section{Instruments}

In this study, a survey method is used as instrument to collect the data. The survey is divided into two sections; Section A and B. The first section is the teacher's personal information such as gender, option and teaching experience. On the other hand, Section B consists of the questions that teachers need to answer. There are 40 items included in the form of positive statements regarding English Language teachers teaching styles. These items are adapted from Grasha' Teaching Style Inventory which were also used by past researchers such as Noriah et al. (1999), Roslind (2003), Ruslin (2008) and Zamri, Nik \& Juliawati (2009); Muhammad, Saoula, Issa \& Ahmed (2019). Likert Scale is used in the questionnaire distributed to the respondents, where each item consists 5 scales varying from 1-Strongly disagree, 2-Disagree, 3-Undecided, 4-Agree, 5-Strongly Agree. The most used teaching style will be determined according to the mean value.

The table below shows the number of questions according to the teaching styles and their positions in the survey.

Table 3: Positions and Number of Questions on Teaching Styles

\begin{tabular}{ccc}
\hline Teaching Style & Question no. & Amount of Questions \\
\hline Expert & $1-8$ & 8 \\
\hline Formal Authority & $9-16$ & 8 \\
\hline Personal Model & $17-24$ & 8 \\
\hline Facilitator & $25-32$ & 8 \\
\hline Delegator & $32-40$ & 8 \\
\hline Total & & 40
\end{tabular}

\section{Procedure}

The teaching styles of English Language Year 6 teachers in Tatau are identified using a survey questionnaire. According to Mathers Fox \& Hunn (2009); halid, Islam \& Ahmed (2019); Alzgool (2019), a questionnaire is one of the methods used to collect survey data. Since those 5 rural schools in Tatau do not have proper Wi-Fi connection and the distance between each rural school takes mostly a few 
INTERNATIONAL JOURNAL OF ACADEMIC RESEARCH IN BUSINESS AND SOCIAL SCIENCES

Vol. 10, No. 3, March, 2020, E-ISSN: 2222-6990 C 2020 HRMARS

hours, teachers can answer the survey through online during weekends. Grasha's Teaching Style Inventory is used to measure the teachers' teaching styles.

\section{Findings}

The respondents for this study are from 5 primary schools in Tatau district. 10 English teachers were purposely chosen to answer the items in the questionnaire. Besides, their teaching style, teachers' profile such as gender, teaching experience and option are also collected. The distribution of teachers according to their profiles are tabulated in Table 3.

Table 4: Distribution of Frequency and Percentage of Teachers' Profile

\begin{tabular}{|c|c|c|}
\hline Profile & Frequency & Percentage (\%) \\
\hline \multicolumn{3}{|l|}{ English Option } \\
\hline - Yes & 4 & 40 \\
\hline - No & 6 & 60 \\
\hline \multicolumn{3}{|c|}{ Gender } \\
\hline - Female & 5 & 50 \\
\hline - Male & 5 & 50 \\
\hline Teaching Experience & & \\
\hline - $0-5$ years & 2 & 20 \\
\hline - 5-10 years & 6 & 60 \\
\hline - 10 years and above & 2 & 20 \\
\hline Total & 10 & 100 \\
\hline
\end{tabular}

Based on Table 3 shown above, among 10 teachers involved with this study, $40 \%$ of them are English option while the other $60 \%$ are not English option. Besides that, the distribution of percentage on the teachers' gender are equal, where both genders have the same percentage. Next, based on their teaching experience, it is found out that $20 \%$ of the teachers have less than 5 years teaching experience, $60 \%$ have almost 10 years teaching experience and the other $20 \%$ have been teaching for more than 10 years. After analysing the data, the findings show that most of the teachers used Delegator style in their teaching (40\%), while Expert style is the second dominant teaching style (20\%) and Personal Model, Formal Authority and Facilitator style respectively scored $10 \%$. 
INTERNATIONAL JOURNAL OF ACADEMIC RESEARCH IN BUSINESS AND SOCIAL SCIENCES Vol. 10, No. 3, March, 2020, E-ISSN: 2222-6990 @ 2020 HRMARS

Table 5: Dominant teaching style employed by teacher

\begin{tabular}{cc}
\hline Teaching Styles & Number / Percentage (\%) \\
\hline Expert & $2 / 20$ \\
\hline Formal Authority & $1 / 10$ \\
\hline Personal Model & $2 / 20$ \\
\hline Delegator & $4 / 40$ \\
\hline Facilitator & $1 / 10$ \\
\hline Total & $10 / 100$ \\
\hline
\end{tabular}

\section{a) Is there any relationship between primary school English teachers' teaching style and their option?}

Based on Table 5, 20\% of the English option teachers employed Expert style in teaching. Meanwhile, for Formal Authority style, 10\% of the English option teachers used this style in their teaching and another $10 \%$ possessed Delegator style. This clearly shows that English Option teachers mostly used Expert Style to teach their pupils. On the other hand, non-English option preferred to use Personal Model, Delegator and Facilitator style. This could possibly imply that English option teachers has more knowledge and expertise compare to non-English teachers. They are also more focussed towards their responsibility in imparting knowledge to their pupils.

Table 6: Percentage of Dominant Teaching Style According to Option

\begin{tabular}{cccc}
\hline Teaching Style & English Option & Number & Percentage (\%) \\
\hline Expert & Yes & 4 & 20 \\
& No & 6 & - \\
\hline Formal Authority & Yes & 4 & 10 \\
& No & 6 & - \\
\hline Personal Model & Yes & 4 & - \\
& No & 6 & 20 \\
\hline Delegator & Yes & 4 & 10 \\
& No & 6 & 30 \\
\hline Facilitator & Yes & 4 & - \\
& No & 6 & 10 \\
\hline Total & & 10 & 100 \\
\hline
\end{tabular}

b) Is there any relationship between primary school English teachers' teaching style and their teaching experience?

Based on Table 6, 30\% of the teachers who employed the dominant style own teaching experience for more than 10 years and another $10 \%$ has been teaching for almost 10 years. Novice teachers can be seen using different teaching styles which Expert and Delegator style. Usually, teachers who just got posted to their workplace are still experimenting with their teaching styles 
INTERNATIONAL JOURNAL OF ACADEMIC RESEARCH IN BUSINESS AND SOCIAL SCIENCES

Vol. 10, No. 3, March, 2020, E-ISSN: 2222-6990 @ 2020 HRMARS

and methods. The first five years are very crucial for novice teachers to explore their own identity and teaching personality. Meanwhile, teachers who have been teaching for more than 10 years are more of Delegator teachers who inculcate the sense of self-independent among their pupils. This probably implies that experienced teachers are more confident with the ability of their pupils to work on tasks alone.

Table 7: Percentage of Dominant Teaching Style according to teaching experience

\begin{tabular}{cccc}
\hline Teaching Style & Teaching Experience & Number & Percentage (\%) \\
\hline Expert & $0-5$ & 2 & 10 \\
& $5-10$ & 6 & 10 \\
& More than 10 & 2 & - \\
\hline Formal Authority & $0-5$ & 2 & - \\
& $5-10$ & 6 & 10 \\
& More than 10 & 2 & - \\
\hline Personal Model & $0-5$ & 2 & 10 \\
& $5-10$ & 6 & 10 \\
& More than 10 & 2 & - \\
\hline Delegator & $0-5$ & 2 & - \\
& $5-10$ & 6 & 30 \\
\hline Facilitator & More than 10 & 2 & - \\
& $0-5$ & 2 & - \\
& $5-10$ & 6 & 10 \\
\hline Total & More than 10 & 2 & 100 \\
\hline
\end{tabular}

c) Is there any relationship between primary school English teachers' teaching style and their gender?

Based on Table 7, Expert style (20\%) are more popular among female teachers compared to Formal Authority (10\%) and Delegator Style (10\%). This possibly shows that female teachers prefer using these teaching styles because they want the pupils to learn the language with discipline. Besides that, teachers who use these styles often see themselves as the "flashlight" of the classroom. On the other hand, Personal Model (20\%) and Delegator style (30\%) are more popular among male teachers. this probably demonstrates that their teaching goals are to be role models and good examples to their pupils. They also have the accountability to demonstrate on how to master skills in English classroom as well as to convey the subject content effectively. 
INTERNATIONAL JOURNAL OF ACADEMIC RESEARCH IN BUSINESS AND SOCIAL SCIENCES Vol. 10, No. 3, March, 2020, E-ISSN: 2222-6990 C 2020 HRMARS

Table 8: Percentage of Dominant Teaching Style according to gender

\begin{tabular}{cccc}
\hline Teaching Style & Gender & Number & Percentage (\%) \\
\hline Expert & Female & $\mathbf{5}$ & $\mathbf{2}$ \\
& Male & $\mathbf{5}$ & $\mathbf{1}$ \\
\hline Formal Authority & Female & $\mathbf{5}$ & \\
& Male & $\mathbf{5}$ & $\mathbf{2}$ \\
\hline Personal Model & Female & $\mathbf{5}$ & $\mathbf{1}$ \\
& Male & $\mathbf{5}$ & $\mathbf{3}$ \\
\hline Delegator & Female & $\mathbf{5}$ & \\
& Male & $\mathbf{5}$ & $\mathbf{1}$ \\
\hline Facilitator & Female & $\mathbf{5}$ & $\mathbf{1 0 0}$ \\
& Male & $\mathbf{5}$ & \\
\hline Total & & 10 & \\
\hline
\end{tabular}

d) Is there any relationship between primary school English teachers' teaching style and pupils' UPSR achievement in Tatau?

All in all, it is found out that Primary 6 English teachers in Tatau employed all 5 teaching styles as proposed by Grasha. However, the most dominant teaching style possessed by teachers is the Delegator style (40\%) followed by Expert Style (20\%) and Personal Model (20\%). These results may vary from other studies due to the size of the respondents, the number of pupils in each class and the pupils' proficiency level in English Language. Most importantly, the findings collected through this study portrays the significance of using diverse teaching styles so that pupils can learn multi learning methods in ESL classroom. Felder and Henriques (1995) highlighted that pupils learn through different ways. Hence, by using various teaching styles and methods in classroom, pupils can acquire target language by exploring different types of learning styles without feeling restricted and bored in classroom.

\section{Conclusion}

To conclude, this study shows that teachers employ their teaching styles according to their teaching environment. The type of teaching styles is also reflected by their gender, option and teaching experience. It is hopeful that in order to ensure good academic achievement among pupils, all parties including parents, school leaders, teachers, community and the pupils themselves need to have their awareness on the importance of quality education.

\section{References}

Adunola, O. (2011). The Impact of Teachers' Teaching Methods on The Academic Performance of Primary School Pupils in Ijebu-Ode Local Cut Area of Ogun State. Ego Booster Books. Ogun, State, Nigeria.

Akinbute, O. (2007). Problems of Teacher Education for Primary Schools in Nigeria: Beyond Curriculum Design and Implementation. International Journal of African \& African American Studies: Vol 5 (2).

Altheide, D. L., \& Johnson, J. M. (1994). Criteria for Assessing Interpretive Validity in 
INTERNATIONAL JOURNAL OF ACADEMIC RESEARCH IN BUSINESS AND SOCIAL SCIENCES Vol. 10, No. 3, March, 2020, E-ISSN: 2222-6990 (C) 2020 HRMARS

Qualitative Research. In N. K. Denzin \& Y. S. Lincoln (Eds.). Handbook of Qualitative Research, Page 485-499. SAGE, Thousand Oaks, California.

Alzgool, M. (2019). Nexus between Green HRM and Green Management towards Fostering Green Values. Management Science Letters, 9(12), 2073-2082.

Arthurs, J. B. (2007). A Juggling Act in The Classroom: Managing Different Learning Styles. Teaching and Learning in Nursing, Vol 2. pg. 2-7.

Ayeni, A. J. (2011). Teachers professional development and quality assurance in Nigerian Secondary Schools. World Journal of Education, Vol 1 (2), pg. 143-149.

Baker, J. D., \& Cooke, J. E. (1998). Beyond Career Choice: The Role of Learning Style Analysis in Residency Training. Medical Education, Vol 22 (6). pg. 557-532.

Barberos, M. T., Gozalo, A., \& Padayogdog, E. (2019). The Effect of The Teacher's Teaching Style on Students' Motivation Action Research. Retrieved From Https://Steinhardt.Nyu.Edu/Teachlearn/Research/Action/Motivation

Carmines, E. G., \& Zeller, R. A. (1979). Reliability and Validity Assessment. SAGE, Newbury Park, California.

Ebrahimi, M. (2016). Relation Between Teaching Methods Versus Academic Achievements of Students. The Caspian Sea Journal: Vol 10, Issue 1, Supplement 4. Pg. 335-355.

Ganyaupfu, E. N. (2013). Teaching Methods and Students' Academic Performance. International Journal of Humanities and Social Science Invention, Vol 2: Issues 9. Pg 29-35.

Grasha, A. F. (1994). A Matter of Style: The Teacher as Expert, Formal Authority, Personal Model, Facilitator and Delegator. College Teaching, Vol 42 (4). Pg 142-149. Heldref Publications.

Grasha, A. F. (1996). Teaching with Style: A practical guide to enhance learning by understanding learning and teaching styles. Pittsburgh, PA: Alliance Publishers

Felder, R. M., \& Henriques, E. R. (1995). Learning and teaching styles in foreign and second language education. Foreign Language Annal, Vol 28(1): pg 21-31.

Khandaghi, M. A., \& Farasat, M. (2011). The Effect of Teacher's Teaching Style on Students' Adjustment. Procedia-Social and Behavioural Sciences, Vol 15. pg. 1391-1394. 21.

Khalid, N., Islam, D. M. Z., \& Ahmed, M. R. M. (2019). Sentrepreneurial Training and Organizational Performance: Implications for Future. Humanities \& Social Sciences Reviews, 7(2), 590-593.

Kovacs, A. (1985). The research process: Essential of skill development. F. A. Davis Company, Philadelphia

Kowoser, E., \& Berman, N. (1996). Comparison of paediatric resident and faculty learning styles: implications for medical education. American Journal of Medical Science, Vol 312(5). Page 214-218.

Mathers, N., Foxx, N., \& Hunn, A. (2009). Surveys and Questionnaires. The NIHR Research Design Service for The East Midlands. NHS Institute of Health Research, Nottingham

McLeod, S. (2015). Simply Psychology: Humanism. Retrieved from https://www.simplypsychology.org/humanistic.html

Mohajan, H. K. (2017). Two criteria for good measurements in research: validity and reliability. Munich Personal RePec Archive. Retrieved from https://mpra.ub.unimuenchen.de/83458/1/MPRA_paper_83458.pdf;Two

Muema, Mulwa \& Mailu. (2018). Relationship Between Teaching Method and Students' 
INTERNATIONAL JOURNAL OF ACADEMIC RESEARCH IN BUSINESS AND SOCIAL SCIENCES

Vol. 10, No. 3, March, 2020, E-ISSN: 2222-6990 @ 2020 HRMARS

Performance in Mathematics in Public Secondary Schools in Dadaab Sub County, Garissa County; Kenya. IOSR Journal of Research \& Method in Education (IOSR-JRME), Vol 8 (5), pg 59-63.

Muhammad, K., Saoula, O., Issa, M., \& Ahmed, U. (2019). Contract Management and Performance Characteristics: An Empirical and Managerial Implication for Indonesia. Management Science Letters, 9(8), 1289-1298.

Norland, E. (2002). Teaching Style: Where are we now? Retrieved from https://doi.org/10.1002/ace.46

Peacock, M. (2001). Match or mismatch. Learning styles and teaching styles in EFL. International Journal of Applied Linguistic, Vol 11(1). Pg.1-20

Simon, M. K. \& Goes J. (2011). Correlational Research. Retrieved from www.dissertationrecipes.com

Simpson, J. A. \& Weiner, E. S. C. (1989). Achievement. Oxford English Dictionary 7 (2nd Edition. Clarendon Press.

Tulbure, C. (2011). Learning Styles, teaching strategies and academic achievement in higher education: A cross-sectional investigation. Procedia-Social and Behavioural Sciences, Vol 33. Page 398-402. 